\title{
Atypical meningioma mimicking high-grade glioma
}

Figure 1 Magnetic resonance imaging

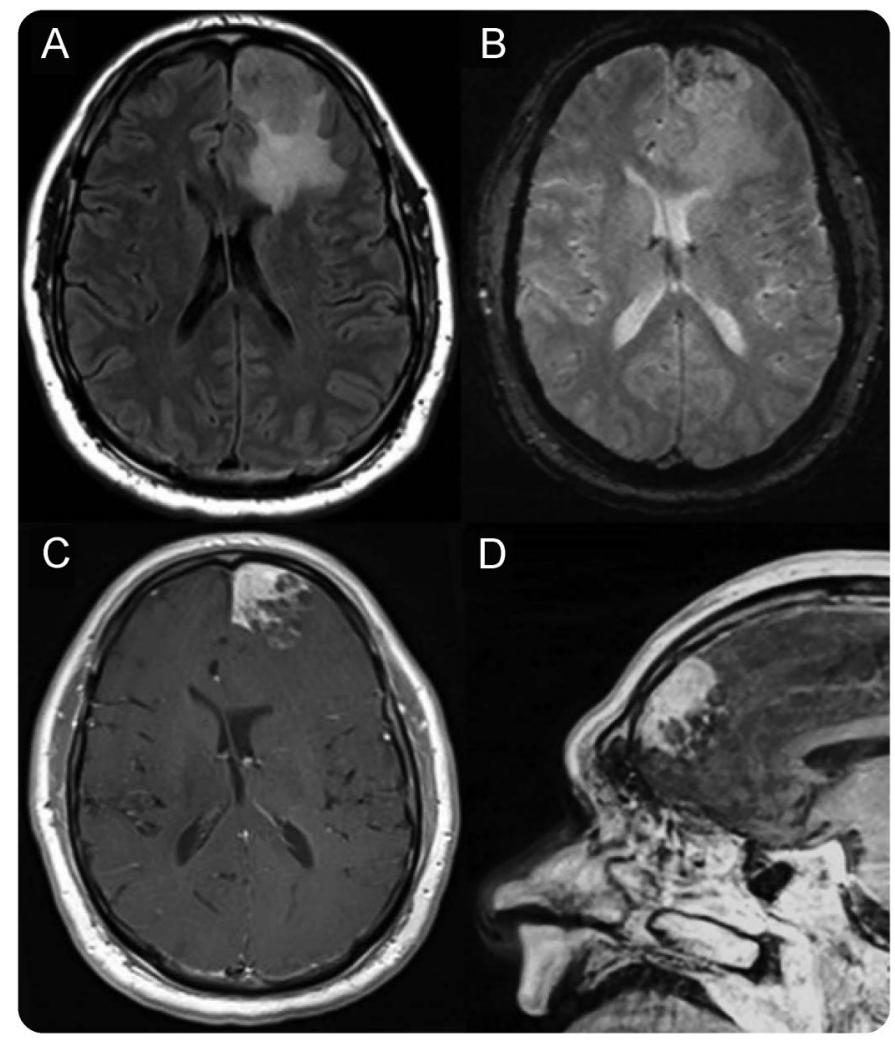

Fluid-attenuated inversion recovery sequence, left frontal mass with infiltrative margins, and vasogenic edema compressing the left lateral ventricle (A). T2-weighted gradient-recalled echo image, foci of hypointensity, attributable to calcification, hemorrhage, or both (B). Post gadolinium-contrast, T1-weighted imaging, heterogeneous contrast enhancement (C, D). No classic signs of meningioma including dural tail, or CSF cleft.

A 52-year-old man presented following a motor vehicle collision. Examination revealed a Glasgow Coma Scale score of 15 , with right lower extremity paresis. Noncontrast CT demonstrated a left frontal lesion. MRI further characterized the mass within the left superior frontal gyrus, suspicious for high-grade glioma (figure 1). Intraoperatively, the mass exhibited invasive margins, gross hypervascularity, and hemorrhage, without apparent dural attachment. Preliminary diagnosis was glial neoplasm. Final pathology was consistent with meningioma with focal brain invasion and rhabdoid differentiation, without anaplastic features, World Health Organization (WHO) grade II (figure 2). Outcome is correlated with WHO grade. ${ }^{1}$ Brain invasion is a new WHO diagnostic criterion of atypical meningioma. ${ }^{2}$

Abdul-Kareem Ahmed, SM, John F. Morrison, MD, Nelli S. Lakis, MD, Edward Stopa, MD, Curtis Doberstein, $M D$

From the Warren Alpert Medical School of Brown University (A.-K.A.); and Department of Neurosurgery (J.F.M., E.S., C.D.) and Division of Neuropathology, Department of Pathology (N.S.L., E.S.), Warren Alpert Medical School of Brown University, Providence, RI. Acknowledgment: The authors thank Glenn Tung, MD, for his preparation of the neuroimaging in this report.

Author contributions: Abdul-Kareem Ahmed: writing, editing manuscript. John F. Morrison: writing, editing manuscript. Nelli S. Lakis: editing manuscript, preparation and interpretation of pathology. Edward Stopa: editing manuscript, interpretation of pathology. Curtis Doberstein: supervision, critical revision of manuscript for content. 


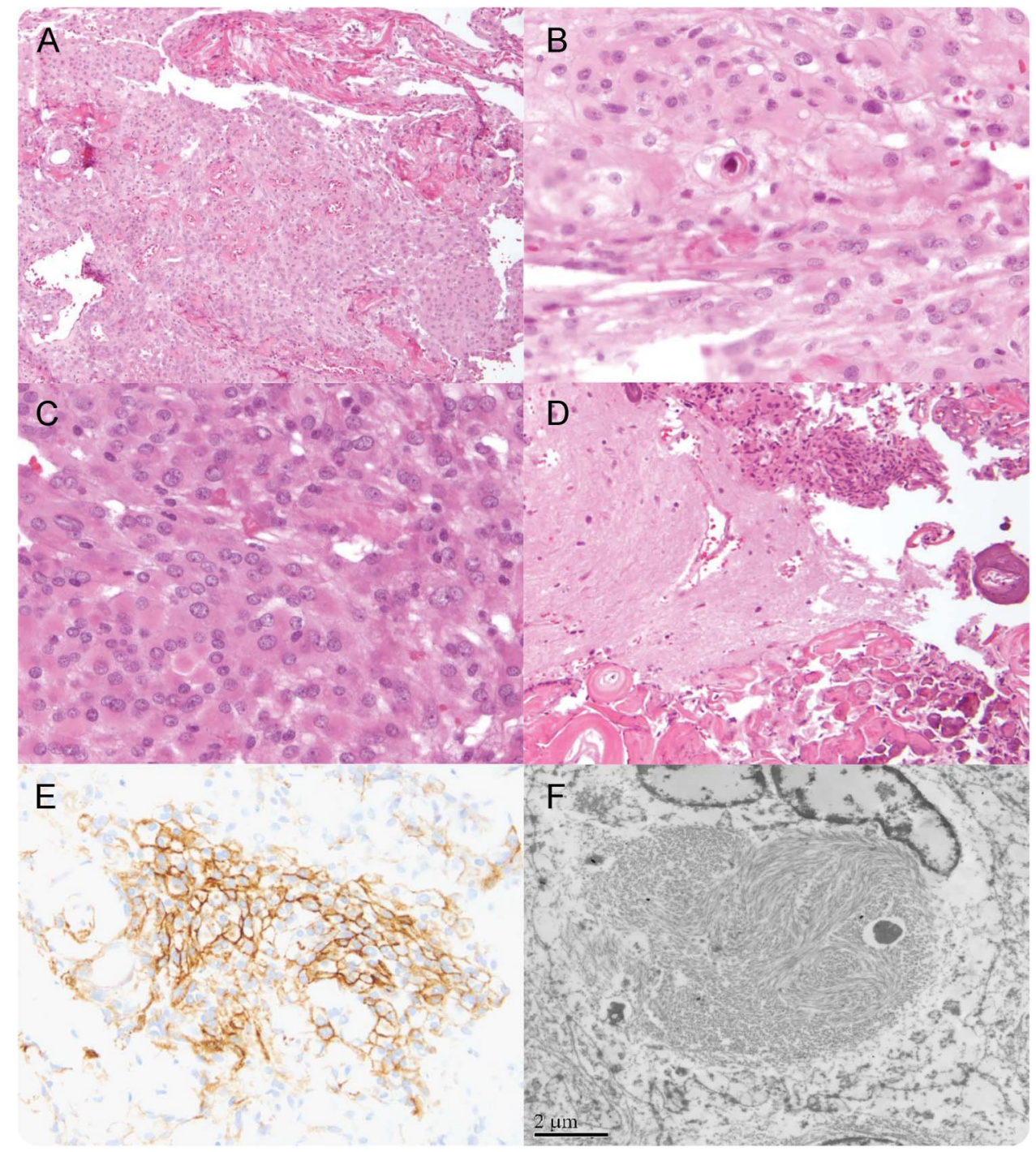

(A) Transitional meningioma with secretory areas, 10× magnification. (B) Rare psammoma body, 40×. (C) Rhabdoid differentiation with eosinophilic cytoplasmic inclusions and nuclei with prominent nucleoli, without frank atypia or mitoses, 40×. (D) Focal brain invasion, 10×. (E) Diffuse epithelial membrane antigen positivity, 40×. (F) Electron microscopy: concentric arrays of intermediate filaments within tumor cells.

Study funding: No targeted funding reported.

Disclosure: The authors report no disclosures relevant to the manuscript. Go to Neurology.org for full disclosures.

Correspondence to Dr. Doberstein: CDoberstein@lifespan.org

1. Vaubel RA, Chen SG, Raleigh DR, et al. Meningiomas with rhabdoid features lacking other histologic features of malignancy: a study of 44 cases and review of the literature. J Neuropathol Exp Neurol 2016;75:44-52.

2. Louis DN, Perry A, Reifenberger G, et al. The 2016 World Health Organization Classification of Tumors of the Central Nervous System: a summary. Acta Neuropathol 2016;131:803-820. 


\section{Neurology}

Atypical meningioma mimicking high-grade glioma

Abdul-Kareem Ahmed, John F. Morrison, Nelli S. Lakis, et al.

Neurology 2016;87;2281-2282

DOI 10.1212/WNL.0000000000003364

This information is current as of November 21, 2016

\section{Updated Information \&} Services

\section{References}

Subspecialty Collections

Permissions \& Licensing

Reprints including high resolution figures, can be found at: http://n.neurology.org/content/87/21/2281.full

This article cites 2 articles, 0 of which you can access for free at: http://n.neurology.org/content/87/21/2281.full\#ref-list-1

This article, along with others on similar topics, appears in the following collection(s):

MRI

http://n.neurology.org/cgi/collection/mri

Primary brain tumor

http://n.neurology.org/cgi/collection/primary_brain_tumor

Information about reproducing this article in parts (figures,tables) or in its entirety can be found online at:

http://www.neurology.org/about/about_the_journal\#permissions

Information about ordering reprints can be found online:

http://n.neurology.org/subscribers/advertise

Neurology ${ }^{\circledR}$ is the official journal of the American Academy of Neurology. Published continuously since 1951, it is now a weekly with 48 issues per year. Copyright @ 2016 American Academy of Neurology. All rights reserved. Print ISSN: 0028-3878. Online ISSN: 1526-632X.

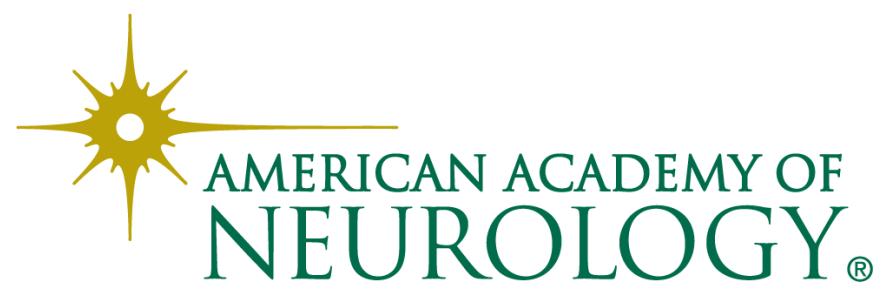

